\title{
EFFECTIVENESS OF THE GUIDED DISCOVERY MODEL BASED VIRTUAL LAB PhET TOWARD MASTERY STUDENTS' CONCEPT ON TOPIC PHOTOELECTRIC EFFECT
}

\section{${ }^{1}$ Muhammad Habibbulloh}

Department of Science Education, Faculty of Teacher Training and Education, Lamongan Islamic University. Jl. Veteran No.53A Lamongan, Indonesia.

Email: habibbulloh@unisla.ac.id

Article History

Received: 25 January

Revised: 19 February

Published: March

\begin{abstract}
Research has been conducted to determine the effectiveness of the guided discovery model based on the virtual lab PhET (Physics Education technology) on mastering students' concepts in the photoelectric effect material. The purpose of this study is describing the feasibility of learning, student activity, and the effectiveness of the model applied to the mastery of student concepts. This type of research is quantitative descriptive with the design of one group pretest-posttest. The data obtained were in the form of learning accuracy questionnaires, student activities, and the results of the pretest and posttest mastery of students' concepts. Analysis of data on implementation and activities of students used percentage of agreement, while mastery of students' concepts was analyzed descriptively quantitatively through homogeneity, normality, and N-gain test. Based on data and analysis, it was concluded that the implementation of categorical learning was very good, student activities were in good category, and guided discovery models based on virtual labs PhET were effectively used to improve mastery of students' concepts in the photoelectric effect material.
\end{abstract}

Keywords: guided discovery model based virtual lab, mastery of students' concepts, photoelectric effect

How to cite: Habibbulloh, Muhammad. (2019). EFFECTIVENESS OF THE GUIDED DISCOVERY MODEL BASED VIRTUAL LAB PhET TOWARD MASTERY STUDENTS' CONCEPT ON TOPIC PHOTOELECTRIC EFFECT. Vol. 1 No.1: 1-9.

\section{INTRODUCTION (12pt)}

Physics learning on the topic of photoelectric effects is one of the discussion material in physics subjects in the XII class of senior high school. Various concepts that are abstract, often and many are found in physics subjects, so this becomes one of the causes of students having difficulty understanding the material ${ }^{[1]}$. The subject of the photoelectric effect is a type of material that is very abstract to be taught. This is due to several factors including the very small size of the subject discussed to the atomic level and the unavailability of supporting laboratory equipment in schools to the strategies chosen by the teacher to explain the material, so that supporting media is needed to teach the abstract concept. One solution used by researchers is the use of the Guided Discovery model combined with the PhET virtual laboratory (Physics Education Technology). Some studies that support the virtual lab is effective in increasing student understanding include the results of Salam, Setiawan, and Hamidah's research on the use of virtual labs on the topic of dynamic electricity ${ }^{[2], ~ S u g i y o n o ' s ~}$ research on the use of PhETs on optical instruments [3], research results Pfefferova about learning activities using computer simulations [4], and Research Marlinda et al., About Phet virtual lab learning on the concept of solubility and solubility results ${ }^{[5]}$. 
The guided discovery learning model is a mixture of teacher-centered and studentcentered [6]. The use of this model is intended so that students can understand the concepts taught to the maximum. Holmes and Hoffman mention three characteristics of guided discovery learning, namely: (1) exploiting and solving problems in order to create, combine, and generalize knowledge, (2) student-centered, teachers only act as facilitators, (3) activities in the model guided discovery to combine new knowledge and existing old knowledge ${ }^{[7] .}$ Through discovery learning, the teacher creates a learning atmosphere that reflects the discovery process for students. Students are given the opportunity to search for and find information from the teaching material being studied. With student involvement and also teacher guidance, students will be more focused on understanding abstract concepts such as the photoelectric effect. The use of this model combined with the virtual lab is expected to be able to answer abstract material problems and lack of school laboratories specifically for the concept of the photoelectric effect. Purnomo et al., Stated that cognitive learning outcomes among students using the guided discovery learning model with conventional learning models had significant differences ${ }^{[8]}$. The results of research by Maulidar et al., show that the increase in the average conceptual understanding and critical thinking skills of students occurs differences. Experimental classes that use guided discovery learning models experience increased understanding of concepts and higher critical thinking skills compared to control classes that use conventional learning ${ }^{[9]}$. Relia et al., In their study stated that when compared to the control class, students in the class using guided discovery learning assisted by a virtual laboratory or experimental class, were more active and easy to understand the concept ${ }^{[10]}$. The effectiveness of the guided discovery model is also reinforced by Harianti's research which concludes that there is influence of the use of guided discovery learning models on the learning outcomes of class VII students in algebraic operating material, Guided Discovery Learning models are more effective than conventional learning models ${ }^{[11] .}$

\section{RESEARCH METHOD}

The type of this study is descriptive quantitative with one group pretest posttest design. This research was conducted in class XII in one of the high schools in Lamongan. The way to determine the sample is to use opportunity sampling techniques or random sampling, namely simple random sampling. The experimental design used is as follows:

Table 1. The Experimental Design

Informations:

\begin{tabular}{llll}
\hline $\mathrm{R}_{1}$ & $\mathrm{O}_{1}$ & $\mathrm{X}$ & $\mathrm{O}_{2}$ \\
\hline $\mathrm{R}_{2}$ & $\mathrm{O}_{1}$ & $\mathrm{Y}$ & $\mathrm{O}_{2}$ \\
\hline
\end{tabular}

$\mathrm{R} 1=$ Experimental class, random samples taken

$\mathrm{R} 2=$ Control class, samples taken randomly,

$\mathrm{X}=$ The Guided Discovery Model based on the PhET virtual lab,

$\mathrm{Y}=$ conventional method,

$\mathrm{O} 1=$ Class before being treated. This class is tested with the matter of the pretest,

$\mathrm{O} 2=$ Class after being treated. This class is tested with the posttest question

The procedure for the research conducted in this design was chosen by two random classes. One class as the experimental class $\left(R_{1}\right)$ and the other class as the control class $\left(R_{2}\right)$. In both classes a pretest was conducted to determine the initial knowledge possessed as well as to test the sample with normal distribution through the normality test of both classes. Furthermore, class $\mathrm{R}_{1}$ is given treatment $\mathrm{X}$, namely the Model Guided Discovery based on the $\mathrm{PhET}$ virtual lab with steps and devices that have been developed ${ }^{[12]}$. Class $\mathrm{R}_{2}$ is treated with 
conventional methods, the method commonly used by teachers in class. Then posttest was given in each class. The t-test was performed on the pretest and posttest values. The purpose of the t-test was to find out whether there was a significant difference in the mastery of students' concepts before and after being guided by a guided discovery model based on virtual labs. The t-test was carried out with the help of SPSS 16.0. Paired t-test conducted using a significance level $\alpha=0.05$ (2-tailed). Test criteria with the t-test have a hypothesis:

$\mathrm{H} 0: \mu 1=\mu 2$, meaning there is no significant difference between the pretest and posttest values. Ha: $\mu 1 \neq \mu 2$, there is a significant difference between the pretest and posttest values.

The hypothesis testing criteria are to reject or not reject H0 based on P-value (in the SPSS 16 program the terms Significance or "Sig" are used) according to Sugiyono ${ }^{[13]}$ are as follows:

If $\mathrm{P}$-value is $<\alpha$, then $\mathrm{H} 0$ is rejected and $\mathrm{Ha}$ is accepted.

If $\mathrm{P}$-value $>\alpha$, then $\mathrm{H} 0$ is accepted and $\mathrm{Ha}$ is rejected.

Before the paired $t$ test is carried out, there are requirements for assumptions that must be met, that the sample data comes from the population with normal distribution.

The normality test aims to find out the sample data obtained comes from a population with normal distribution or not. After getting the pretest value, the data was tested for normality. The statistical test used was the Saphiro-Wilk test reinforced with KolmogorovSmirnov through the help of SPSS 16.0 with a significance level of $\alpha=0.05$ (2-tailed). The form of the hypothesis for the normality test is as follows:

$\mathrm{H} 0: \mu 1=\mu 2$, meaning that the data sample comes from a population with normal distribution Ha: $\mu 1 \neq \mu 2$, meaning the sample comes from the population not normally distributed Criteria for testing hypotheses to reject or not reject $\mathrm{HO}$ based on $\mathrm{P}$-value.

Furthermore, the pretest and posttest values were analyzed by the N-gain technique. The N-gain technique is used to determine the increase in mastery of students' concepts while strengthening the results of the t-test. The following is the gain technique equation according to Hake ${ }^{[14]}$ :

$$
\mathrm{N} \text {-gain }=\frac{\text { Spost }- \text { Spre }}{\text { Smax }- \text { Spre }}
$$

With:

$\mathrm{N}$-gain = gain value $\quad$ Spost $=$ posttest value

Spre $=$ value of pretest $\quad$ Smax $=$ maximum value

Calculations with the $\mathrm{N}$-gain technique can be converted based on the criteria in table $2^{[14]}$.

Table 2. Criteria of Normalized Gain

\begin{tabular}{cc}
\hline N-gain Score & $\begin{array}{c}\text { Criteria of } \\
\text { Normalized Gain }\end{array}$ \\
\hline$N$-Gain $>0,70$ & High \\
$0,30 \leq N$-Gain $\leq 0,70$ & Middle \\
$N$-Gain $<0,30$ & Low \\
\hline
\end{tabular}

During the learning process an assessment of 2 observers is given through the implementation of the learning and activity student rubric. The level of reliability of the data instruments from the two observers is matched using the formula Percentage of agreement (PA) equation (2) according to Borich [15] as follows:

$P A=\left(1-\frac{A-B}{A+B}\right) \times 100 \%$ 
Percentage of agreement $(\mathrm{PA})=$ the level of compatibility of two observers

$\mathrm{A}=$ the frequency of aspects that give a high value

$\mathrm{B}=$ frequency of aspects that give a low value

the instrument is said to be suitable if it has a match level of $\geq 75 \%$.

\section{RESULTS AND DISCUSSION (12pt)}

The results of research data obtained from the rubric of student activity and the implementation of learning are presented in table 3 and table 4:

Table 3. Student activity data through observation rubrics during the learning process

\begin{tabular}{|c|c|c|c|c|}
\hline \multirow[t]{2}{*}{$\#$} & \multirow[t]{2}{*}{ Aspects observed } & \multicolumn{2}{|c|}{$\begin{array}{l}\text { Percentage of Activity of } \\
\text { Students Each RPP } \\
\text { (Lesson Plan) / Meeting }\end{array}$} & \multirow[t]{2}{*}{ Average \% } \\
\hline & & 1 & 2 & \\
\hline 1. & Listen to the teacher's explanation & 90,63 & 96,88 & 93,76 \\
\hline 2. & $\begin{array}{l}\text { Make a guess / hypothesis about the misconception of } \\
\text { the photoelectric effect through cognitive conflict }\end{array}$ & 75,00 & 78,13 & 76,57 \\
\hline 3. & Reading handout & 21,88 & 18,75 & 20,32 \\
\hline 4. & Working on Photoelectric Effect LKS (worksheets) & 100,00 & 100,00 & 100,00 \\
\hline 5. & Identify variables & 90,63 & 93,75 & 92,19 \\
\hline 6. & Perform experiments with virtual labs & 84,38 & 90,63 & 87,51 \\
\hline 7. & Collect the data & 90,63 & 98,88 & 94,76 \\
\hline 8. & Analyze data & 90,63 & 93,75 & 92,19 \\
\hline 9. & Have group discussions & 81,25 & 87,50 & 84,38 \\
\hline 10. & Present the results of the experiment & 62,50 & 65,63 & 64,07 \\
\hline 11. & Answer and respond to the presentation of other groups & 90,63 & 93,75 & 92,19 \\
\hline 12. & Conclude the results of the class discussion & 68,75 & 75,00 & 71,88 \\
\hline \multirow[t]{2}{*}{13.} & Communicate information to classes and teachers & 87,50 & 90,63 & 89,07 \\
\hline & Total average & & & 81,21 \\
\hline
\end{tabular}

Based on the Table 3, some student activities observed by the observer as a whole showed that activity in the guided discovery model was well implemented. Among them are listening to the teacher's explanation, making guesses/hypotheses about the misconceptions of the Photoelectric Effect through cognitive conflict, reading the Handout, working on the Photoelectric Effect LKS (worksheets), identifying variables, conducting experiments with virtual labs, collecting data, analyzing data, conducting group discussions, presenting experimental results, answering experimental results, answering and respond to the presentation of other groups, conclude the results of class discussions, and communicate information to the class and the teacher. 
Table 4. Learning Outcomes Data in $R_{1}$ class

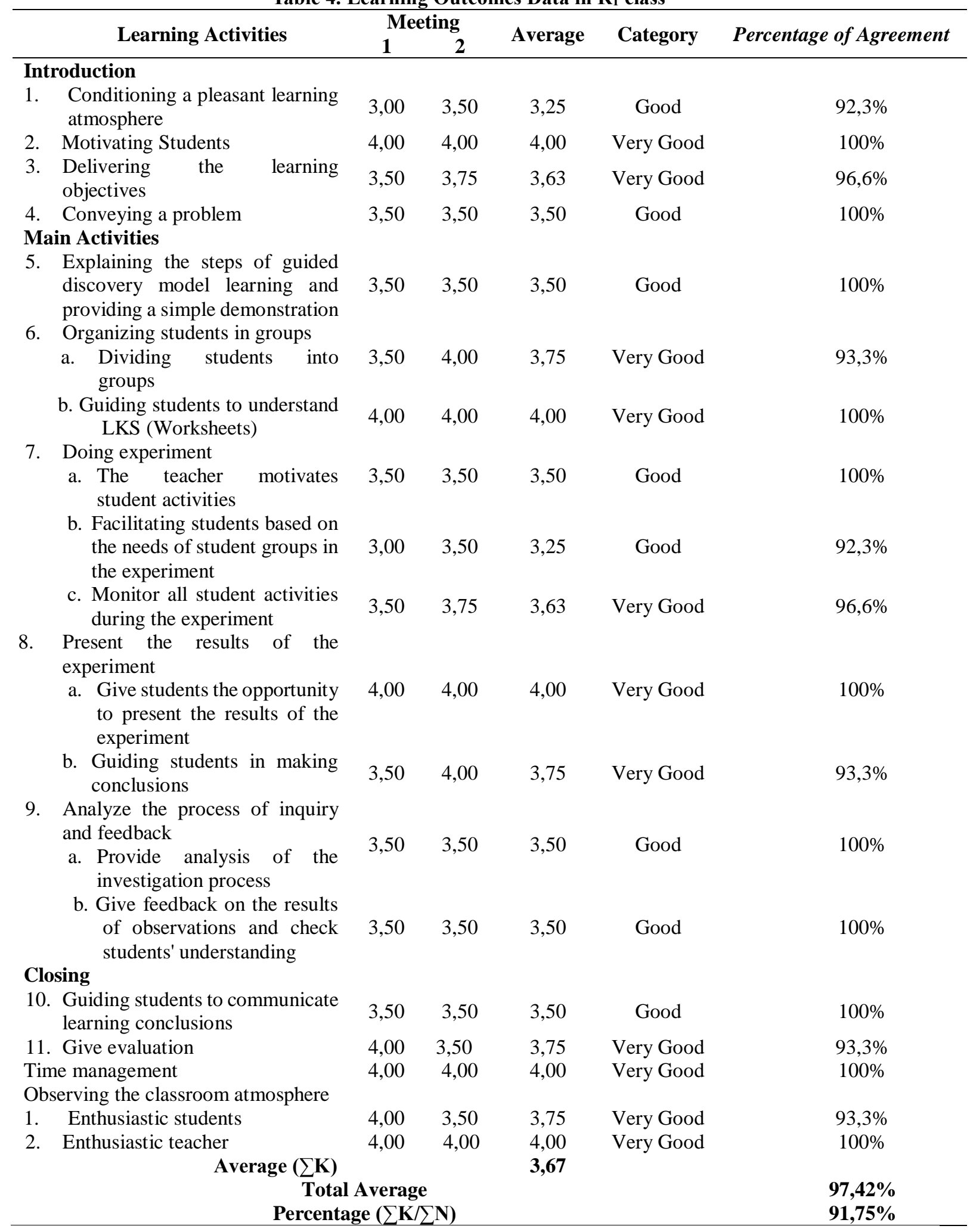

Based on the data in Table 4, it can be seen that the implementation of learning activities using the guided discovery model based on virtual labs has been fully implemented well in class $\mathrm{R}_{1}$. This can be seen from the value of the Percentage of Agreement in the initial activity, the core and closing has a very high percentage and the average total PA is $97.42 \%$. Next step 
to prove the effectiveness of the guided discovery model based on virtual labs, pretest samples were tested whether the samples were normally distributed. The results of the normality test for the pretest class $R_{1}$ and $R_{2}$ are outlined in Table 5 and Table 6 :

Tabel 5. Tests of Normality $\mathbf{R}_{1}$

\begin{tabular}{lcccccc}
\hline & & \multicolumn{2}{c}{ Kolmogorov-Smirnov ${ }^{\mathrm{a}}$} & & \multicolumn{3}{c}{ Shapiro-Wilk } \\
& Statistic & $\mathrm{df}$ & Sig. & Statistic & df & Sig. \\
\hline Pretest $\mathrm{R}_{1}$ & .144 & 20 & $.200^{*}$ & .910 & 20 & .063 \\
\hline
\end{tabular}

Tabel 6. Tests of Normality $\mathbf{R}_{2}$

\begin{tabular}{lcccccc}
\hline & & \multicolumn{2}{c}{ Kolmogorov-Smirnov ${ }^{\mathrm{a}}$} & \multicolumn{3}{c}{ Shapiro-Wilk } \\
& Statistic & df & Sig. & Statistic & df & Sig. \\
\hline Pretest $\mathrm{R}_{2}$ & .199 & 20 & .037 & .914 & 20 & .077 \\
\hline
\end{tabular}

Based on the results of the pretest sample normality test that has been done with SPSS 16.0 and outlined in Table 5 and Table 6 , it is seen that the significance value with the ShapiroWilk model is more than 0.05 . This shows that $\mathrm{HO}$ is accepted and $\mathrm{Ha}$ is rejected. The conclusions that can be drawn from Table 5 and Table 6 are data samples originating from populations with normal distribution.

After the sample is stated to be from a normal distribution population, the pretest and posttest sample data will be carried out t-test to test and prove whether there are significant differences between the results of the two pretest and posttest samples. The results of the t-test pretest and posttest samples are outlined in Table 7 and Table 8

Tabel 7. Paired Samples Test $\mathbf{R}_{1}$

\begin{tabular}{|c|c|c|c|c|c|c|c|c|c|}
\hline & & \multirow{3}{*}{ Mean } & \multicolumn{4}{|c|}{ Paired Differences } & \multirow{3}{*}{$\mathrm{T}$} & \multirow{3}{*}{ Df } & \multirow{3}{*}{ Sig. (2-tailed) } \\
\hline & & & Std. & & $95 \%$ Confic & $\begin{array}{l}\text { aterval of the } \\
\text { ce }\end{array}$ & & & \\
\hline & & & Deviation & Mean & Lower & Upper & & & \\
\hline Pair 1 & $\begin{array}{l}\text { Pretest - } \\
\text { Posttest }\end{array}$ & -23.000 & 11.169 & 2.497 & -28.227 & -17.773 & -9.210 & 19 & .000 \\
\hline
\end{tabular}


Tabel 8. Paired Samples Test $\mathbf{R}_{2}$

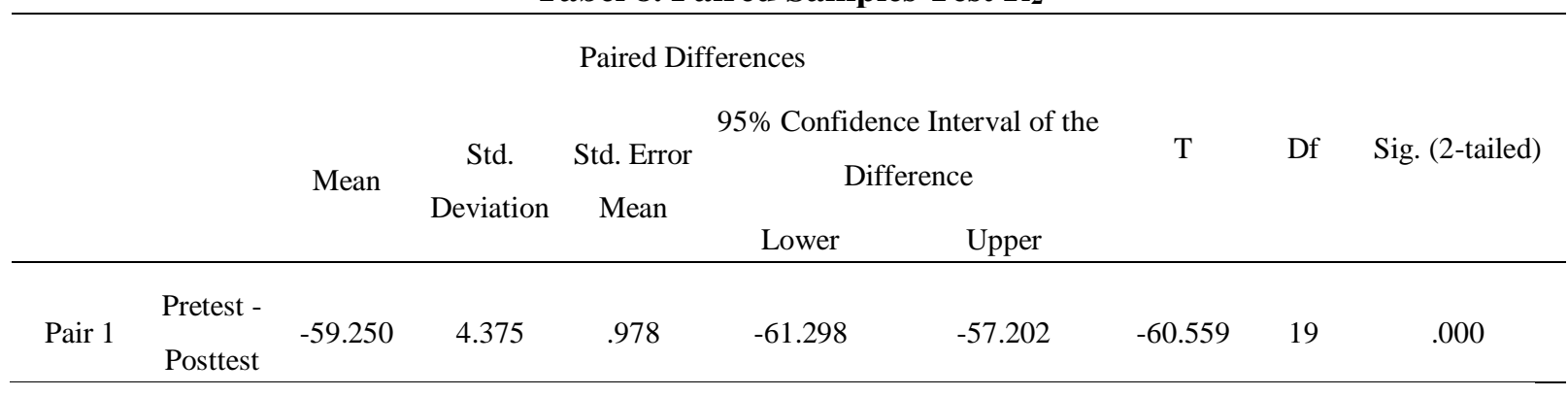

Based on Table 7 and Table 8 , the results show that each class $R_{1}$ and $R_{2}$ have a significance of less than 0.05 . This shows that the $\mathrm{P}$-value $<\alpha$, then $\mathrm{H} 0$ is rejected and $\mathrm{Ha}$ is accepted. So it can be concluded that there are significant differences between the values of the pretest and posttest classes $R_{1}$ and $R_{2}$. Class $R 1$ is an experimental class given a guided discovery model based on the PhET virtual lab, while class $\mathrm{R}_{2}$ is a control class with a conventional model. To strengthen the argumentation of the effectiveness of the guided discovery model based on the PhET virtual lab, an analysis using Gain techniques was carried out. The following table 9 is the result of $\mathrm{N}$-Gain classes $\mathrm{R}_{1}$ and $\mathrm{R}_{2}$ :

Table 9. N-Gain Class $R_{1}$ and $R_{2}$

\begin{tabular}{cccccc}
\hline Student & $\begin{array}{c}\text { Class R } \\
\text { N-Gain }\end{array}$ & Category & Student & $\begin{array}{c}\text { Class R2 } \\
\text { N-Gain }\end{array}$ & Category \\
\hline A & 0,81 & High & A & 1,00 & High \\
B & 0,75 & High & B & 0,60 & Middle \\
C & 0,73 & High & C & 0,55 & Middle \\
D & 0,87 & High & D & 0,56 & Middle \\
E & 0,92 & High & E & 0,55 & Middle \\
F & 0,87 & High & F & 0,60 & Middle \\
G & 0,81 & High & G & 0,50 & Middle \\
H & 0,92 & High & H & 0,33 & Middle \\
I & 0,85 & High & I & 0,33 & Middle \\
J & 0,92 & High & J & 0,45 & Middle \\
K & 0,86 & High & K & 0,60 & Low \\
L & 0,93 & High & L & 0,11 & Middle \\
M & 0,80 & High & M & 0,63 & Middle \\
N & 0,85 & High & N & 0,44 & Low \\
O & 1,00 & High & O & 0,11 & Low \\
P & 0,73 & High & P & 0,25 & Low \\
Q & 0,79 & High & Q & 0,17 & Low \\
R & 0,77 & High & R & 0,18 & Middle \\
S & 0,86 & High & S & 0,58 & Middle \\
T & 0,80 & High & T & 0,60 & Middle \\
\hline
\end{tabular}

Based on Table 9, it can be seen that the $\mathrm{N}$-Gain both classes $\mathrm{R}_{1}$ and $\mathrm{R}_{2}$ have significant differences in terms of individuals and class averages. At the individual level, class $\mathrm{R}_{1}$ has a relatively high and high $\mathrm{N}-$ Gain value, while class $\mathrm{R}_{2}$ has a varied $\mathrm{N}-$ Gain with moderate and low dominance. At the average level the class also experiences something similar to the individual level. Class $\mathrm{R}_{1}$ with a mean value of $\mathrm{N}$-Gain 0.84 with a high category, while class $\mathrm{R}_{2} \mathrm{~N}$-Gain mean value is 0.46 with a medium category. This shows that it has been statistically proven through normality test, t-test, and strengthened by $\mathrm{N}$-Gain analysis that guided 
discovery learning model based on virtual PhET lab is effectively used to improve students' understanding of the photoelectric effect material

\section{CONCLUSION}

Referring to the results and analyzes that have been carried out where based on the analysis of the implementation of learning that is carried out fully has a very good category with an average value of the total percentage of agreement reaching $97.42 \%$. Analysis of student activities is categorized as good with a percentage of $81.21 \%$. The guided discovery learning model based on the virtual PhET lab also proved effective to be used to improve students' understanding of the photoelectric effect material. This can be traced from the normality data of the sample, the pretest and posttest t-test for each class and supported by individual and class $\mathrm{N}$-Gain data. This fact is in accordance with previous research that supports, among others, Sugiyono ${ }^{[3]}$, Pfefferova ${ }^{[4]}$, Maulidar, et al. ${ }^{[9],}$ and Relia et al. ${ }^{[10]}$

\section{SUGGESTIONS}

Suggestions for the contribution of science education in the future, guided discovery models based on the PhET virtual lab can be developed for science material with abstract characteristics and difficult to understand with conventional learning such as photoelectric effects. Device development is very much needed considering the limited use of virtual labs on a national scale, especially in Lamongan, East Java..

\section{ACKNOWLEDGMENT}

Special acknowledgments for The Head of Lamongan Islamic University (UNISLA), The Dean Faculty of Teacher Training and Education (FKIP), opportunities given in conducting research

\section{REFERENCES}

[1] Gönen S. A Study on Student Teachers' Misconceptions and Scientifically Acceptable Conceptions About Mass and Gravity. Published Online. Springer Science Business Media; 2007. DOI: http://doi.org/10.1007/s10956-007-9083-1.

[2] Salam H, Setiawan A, dan Hamidah I. Pembelajaran Berbasis Virtual Laboratory untuk Meningkatkan Penguasaan Konsep pada Materi Listrik Dinamis. Proceedings of The 4th International Conference on Teacher Education; Join Conference UPI \& UPSI; 2010. Terdapat pada:

http://file.upi.edu/Direktori/PROCEEDING/UPIUPSI/2010/Book_4/PEMBELAJARAN_BERBA SIS_VIRTUAL_LABORATORY_UNTUK_MENINGKATKAN_PENGUASAAN_KONSEP_P ADA_MATERI_LISTRIK_DINAMIS.PDF

[3] Sugiyono. Penggunaan PhET dan KIT Sederhana untuk SMA Pokok Bahasan Alat-Alat Optik untuk Meningkatkan Keterampilan Proses dan Belajar Kooperatif. Tesis. Tidak dipublikasikan. Surabaya: Pascasarjana Universitas Negeri Surabaya; 2011

[4] Pfefferova MS. Computer Simulations and their Influence on Students' Understanding of Oscillatory Motion. Informatics in Education. 2015; 14(2): 279-289. DOI: http://doi.org/10.15388/infedu.2015.16.

[5] Marlinda, Halim A., dan Maulana I. 2016. Perbandingan Penggunaan Media Virtual Lab Simulasi PhET (Physics Education Technology) Dengan Metode Eksperimen Terhadap Motivasi Dan Aktivitas Belajar Peserta Didik Pada Materi Kelarutan Dan Hasil Kali Kelarutan. Jurnal Pendidikan Sains Indonesia, Vol.04, No.02, hlm. 69-82, 2016. http://jurnal.unsyiah.ac.id/jpsi

[6] Carin, Arthur A. 1993. Teaching Science Through Discovery seventh edition. New York: Macmillan Publishing Company.

[7] Bicknell-Holmes, T. and Hoffman, P. S. 2000. Elicit, Engage, Experience, Explore: Discovery Learning in Library Instruction. Reference Services Review. 28(4), 313 - 322 
[8] Purnomo H. Y., Mujasam, dan IrfanY. 2016. Penerapan Model Guided Discovery Learning Pada Materi Kalor Terhadap Hasil Belajar Kognitif Peserta Didik Kelas Vii Smpn 13 Prafi Manokwari Papua Barat. Pancaran, Vol. 5, No. 2, hal 1-14 Mei 2016

[9] Maulidar N, Yusrizal, dan Halim. 2016. Pengaruh Penerepan Model Pembelajaran Guided Discovery Terhadap Kemampuan Pemahaman Konsep Dan Ketrampilan Berpikir Kritis Siswa SMP Pada Materi Kemagnetan. Jurnal Pendidikan Sains Indonesia, Vol. 04, No.02, hlm 69-75, 2016. http://jurnal.unsyiah.ac.id/jpsi

[10] Relia A., dan Sodikin. 2018. Pengaruh Pembelaran Guided Discovery Berbantu Laboratorium Virtual Terhadap Pemahaman Konsep Siswa Pada Materi Momentum Dan Impuls. Indonesian Journal of Science and Mathematics Education 01 (2) (2018) 13-21. E-ISSN: 2615-8639 https://ejournal.radenintan.ac.id/index.php/IJSME/index

[11] Harianti, F. 2018. Pengaruh Model Pembelajaran Guided Discovery Learning Terhadap Kemampuan Pemahaman Dan Hasil Belajar Siswa Materi Operasi Aljabar Kelas VII SMP. MUST: Journal of Mathematics Education, Science and Technology Vol. 3, No. 1, Juli 2018 Hal 82 - 91

[12] Habibbulloh M., Jatmiko B., Widodo W. 2017. Pengembangan Perangkat Pembelajaran Model Guided Discovery berbasis Lab Virtual untuk Mereduksi Miskonsepsi Siswa Smk Topik Efek Fotolistrik. Vol 07, No 01, Juni 2017, Jurnal Penelitian Fisika dan Aplikasinya (JPFA) p-ISSN: 2087-9946, e-ISSN: 2477-1775. DOI: http://dx.doi.org/10.26740/jpfa.v7n1.p27-43

[13] Sigiyono. 2015. Metode Penelitian Pendidikan (Pendekatan Kuantitatif, Kualitatif, dan R\&D). Bandung: Alfabeta.

[14] Hake R. R. 1999. American Educational Research Association's Division, Measurement Research Methodology Analyzing Change/Gain Scores. USA: Woodland Hills

[15] Borich, Gary D.1994. Observation Skill for Effective Teaching. New York: Mac Millian Publishing Company 